\title{
Research of Polyocarboxy Acid Water-reducer With Modified Ployether and its Effect on Concrete's Workability
}

\author{
Lufeng Pang ${ }^{1, a}$, Xinxin Zhou ${ }^{2, b}$ \\ ${ }^{1}$ Shandong Jianzhu Univercity No.1000FengMing Road, LinGang Development Zone, Jinan \\ LiCheng Ou, China \\ ${ }^{2}$ Shandong HuaDi building technology Co., LTD Room701,Unit2,BuildingNo.4,HuGuangShanSe \\ Subdistrict, No.6Beiguan North Road, Jinan ,Shandong Province, China \\ apanglufeng@tom.com, bzhouxinxin83@yahoo.com.cn
}

\begin{abstract}
Key words: modified ployether, cement net fluidity, concrete slump, High Performance Liquid Chroma-tography (HPLC), workability
\end{abstract}

\begin{abstract}
In this paper, polycarboxylic type high performance water reducers have been synthesized through using TPEG modified monomer. If synthetic temperature and addition time of copolymer monomers can be controlled, the performance of polycarboxylic superplasticizer will be improved. Testing results indicates that when temperature is at $60 \sim 65^{\circ} \mathrm{C}$, addition time of copolymer monomers is three hours, the performance of superplasticizer is best. Through High Performance Liquid Chroma- tography (HPLC) testing, we can find it is almost the same with the famous brand abroad of the same type. The ues of polycarboxylic type high performance water reducers cooperated with naphthalene series high range water reducing agents thereby markedly improv the workability of concrete mixture.
\end{abstract}

\section{Introduction}

The molecular structure of polycarboxylic superplasticizer is changeful and tunable. It can be changed through changing the factors influencing on the performance of the reducer, such as monomers' type, monomer ratio on processes, chain-length, the dosage of initiator, the kind and dosage of chain transfer agent, the temperature and the reactive time. On the basis of referential review of domestic and foreign bibliography ${ }^{[1-5]}$, the admixture with High Degree of Polymerization backbones and short branches has good slump retention ability. The admixture, in contrast, and with a lot of $-\mathrm{SO}_{3} \mathrm{H}$, can get excellent water-reducing performance and compatibility with cement.

Monomer largely determines the performance of polycarboxylic type high performance water reducers. So we choose modified ployether TPEG synthesiz the admixture. Through the choice of reasonable ratio of monomers and controlling of temperature and the monomer dropping speed we have controlled the performance of polycarboxylic type high performance water reducers well.

\section{Synthesize of Polyocarboxy Acid Water-reducer}

\section{Raw materials}

Modified ployether TPEG; initiating agent; catalyst; chain transfer agent; deionized water, acrylic acid

\section{Synthetic process}

Modified ployether, deionized water, are put into a 4 _mouth flask, heated to $65^{\circ} \mathrm{C}$ initiator is added and then drop other monomers and chain transfer agent progressively, reacted for $3 \mathrm{~h}$, followed by temperature remains unchanged for 1.5 hour and then neutralized and a lot of water is put into the 4_mouth flask. Then we get it.

We keep the quantity of monomer, initiator and chain transfer agent unchanged, then discuss the influence of synthesize temperature and the dropping speed of poly monomer to the performance of polyocarboxy acid water-reducer. 
Control of synthesize temperature.

Temperature is a very important factor in free radical chain polymerization reaction. In this paper we choosed the condition of the reaction temperature at $55^{\circ} \mathrm{C}, 60^{\circ} \mathrm{C}, 65^{\circ} \mathrm{C}, 70^{\circ} \mathrm{C}, 75^{\circ} \mathrm{C}$, get results showed in Table 1.

Table 1 Performance of admixture at different temperature

\begin{tabular}{|l|c|c|}
\hline Temperature $\left[{ }^{\circ} \mathrm{C}\right]$ & $\begin{array}{c}\text { the flowability of neat } \\
\text { cement }[60 \mathrm{~min}] / \mathrm{mm}\end{array}$ & $\begin{array}{c}\text { flowability of neat cement } \\
{[60 \mathrm{~min} / \mathrm{mm}}\end{array}$ \\
\hline 55 & 240 & 200 \\
\hline 60 & 270 & 250 \\
\hline 65 & 270 & 280 \\
\hline 70 & 240 & 250 \\
\hline 75 & 200 & 160 \\
\hline
\end{tabular}

Testing results in Table 1 showed that the performance of admixture was excellent when the temperature was at $60 \sim 65^{\circ} \mathrm{C}$. Especially when at $65^{\circ} \mathrm{C}$, the initial flowability of neat cement was $270 \mathrm{~mm}$ and it enlarged after one hour. When the temperature was higher or lower the performence became poor. When at $70^{\circ} \mathrm{C}$, the flowability of cement net of one hour improved. It may be because when at $60 \sim 65$, the initiator was at the most proper decomposition temperature. When it decreased the initiator decomposed very slowly, then affected the chain polymerization of admixture. While on the contrary, initiator decomposed in very short time, the chain of admixture would be very short. So slump retention ability could get affect.

Controller of synthesis addition time of copolymer monomers

Table 2 Performance of admixture with different addition time

\begin{tabular}{|l|c|c|}
\hline Addition time[hour] & $\begin{array}{c}\text { flowability of neat cement } \\
{[\text { initial }] / \mathrm{mm}}\end{array}$ & $\begin{array}{c}\text { flowability of neat cement } \\
{[60 \mathrm{~min}] / \mathrm{mm}}\end{array}$ \\
\hline 2 & 210 & 180 \\
\hline 2.5 & 260 & 250 \\
\hline 3 & 270 & 260 \\
\hline 3.5 & 260 & 250 \\
\hline 5 & 250 & 220 \\
\hline
\end{tabular}

Testing results in Table 2 showed that the performance of admixture was excellent when the addition time was for about 2.5 3.5 hours. Especially for 3 hours, the initial fluidity of cement net was $270 \mathrm{~mm}$ and almost no fluidity loss after one hour. When the time was less than 2 hour, the performance became very poor. When more than 3.5 hours, the performance had no improvement and when for 5 hours the slump retention ability became poor. It may be because when the time was short, the chain polymerization of admixture was deficient. When the time became long, some side chains shed off, while the costs increased.

Properties tests of admixture

Microcosmic performance test 


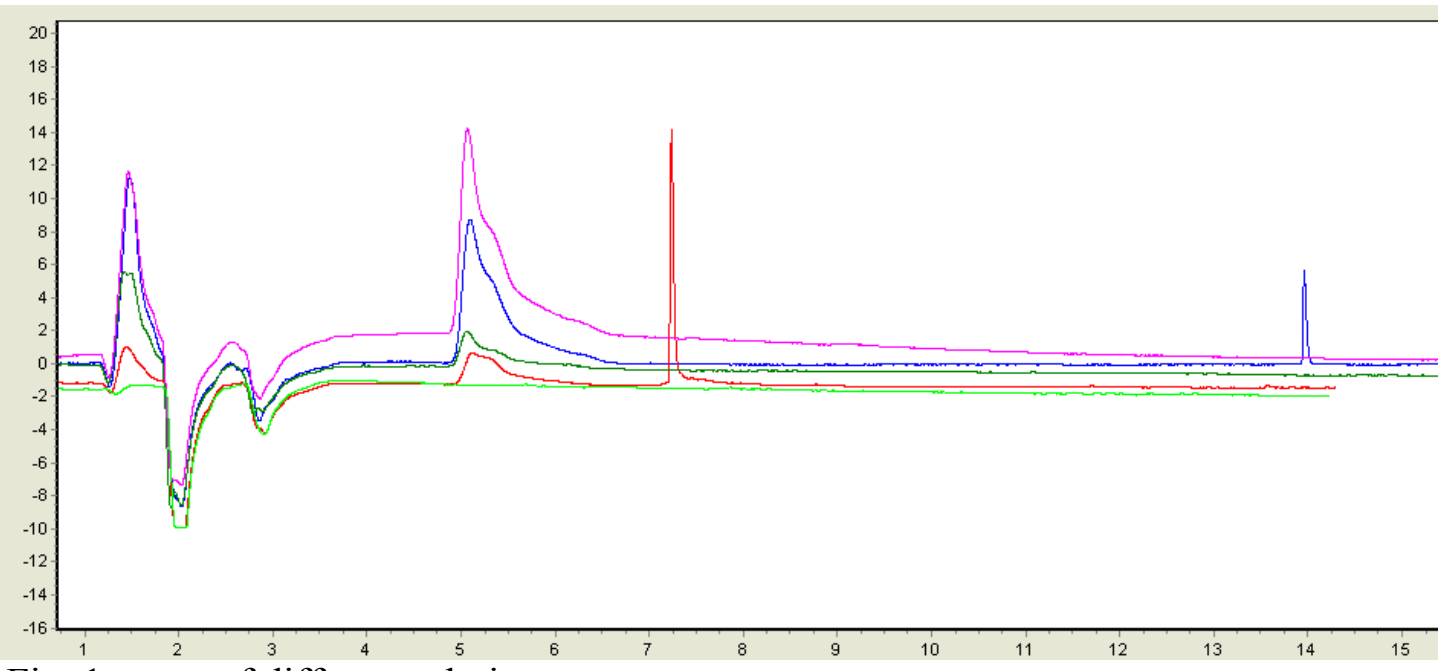

Fig. 1 curve of different admixture

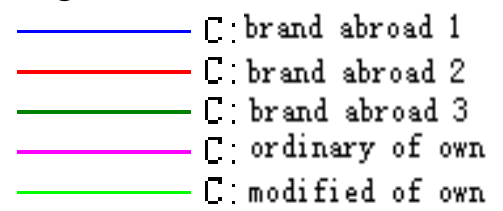

From Fig.1, we can find that our modified admixture's graph is almost the same with the famous brand abroad 3.

Concrete tests We chose concrete of C50 to do tests.

\section{Test materials.}

Cement: P.O52.5; Shandong Cement Plant

Mineral powder: from Luxin Mineral powder factory

Fly ash: from Huangtai Power Plant

Water: potable water

Admixture: polycarboxylic type high performance water reducers from abroad and own

Sand: river sand from Taian; $\mathrm{Mx}=2.6$

Gravel: 5-25mm; powdered stone

Concrete Mix Ratio The concrete mix ratio is as Table 3.

Table 3 Concrete Mix Ratio $\left[\mathrm{kg} / \mathrm{m}^{3}\right]$

\begin{tabular}{|c|c|c|c|c|c|c|}
\hline $\begin{array}{l}\text { strength } \\
\text { grade }\end{array}$ & cement & $\begin{array}{l}\text { mineral } \\
\text { powder }\end{array}$ & Fly ash & sand & grate & water \\
\hline C50 & 380 & 60 & 60 & 752 & 1180 & 165 \\
\hline
\end{tabular}

Table 4 Concrete test results

\begin{tabular}{|c|c|c|c|c|c|}
\hline \multirow{2}{*}{ test } & \multirow{2}{*}{$\begin{array}{l}\quad \text { Dosage of } \\
\text { admixture } \\
\text { (percentage of } \\
\text { cementing } \\
\text { materials) }\end{array}$} & \multicolumn{2}{|c|}{ Slump $[\mathrm{mm}]$} & \multicolumn{2}{|l|}{ working condition } \\
\hline & & Initial & $60 \mathrm{~min}$ & Initial & $60 \mathrm{~min}$ \\
\hline 1 & $0.22 \%$ & 250 & 220 & $\begin{array}{l}\text { good fluidity, } \\
\text { gravels show out and } \\
\text { paste bleed }\end{array}$ & $\begin{array}{l}\text { good fluidity, } \\
\text { good workability }\end{array}$ \\
\hline 2 & $0.2 \%$ & 240 & 170 & $\begin{array}{l}\text { good fluidity, } \\
\text { gravels show out and } \\
\text { paste bleed }\end{array}$ & $\begin{array}{l}\text { flowing with little } \\
\text { speed, slump loss a } \\
\text { lot }\end{array}$ \\
\hline 3 & $0.18 \%$ & 220 & 150 & $\begin{array}{l}\text { good work condition, } \\
\text { excellent workability }\end{array}$ & $\begin{array}{l}\text { no flowing, } \\
\text { large slump loss }\end{array}$ \\
\hline 4 & $0.15 \%$ & 200 & 100 & $\begin{array}{l}\text { good work condition, } \\
\text { excellent workability }\end{array}$ & $\begin{array}{l}\text { no flowing, large } \\
\text { slump loss }\end{array}$ \\
\hline
\end{tabular}


Concrete test results in Table 4 indicated that when the dosage of the admixture was larger the initial condition of the concrete mixture showed good fluidity but the bigger gravels showed out and cement paste bleed. However when the dosage was lower the initial condition was excellent but the concrete slump loss was large.

So we chose some auxiliary materials such as $\mathrm{YQ}, \mathrm{HJ}, \mathrm{HN},-\mathrm{C}$, introduced into the admixture to do concrete tests. We chose the dosage of admixture was all $0.18 \%$ of cementing materials. The results were listed in Table 5.

Table 5 Compounds Test Results

\begin{tabular}{|c|c|c|c|c|c|c|c|}
\hline \multirow[t]{2}{*}{ test } & \multicolumn{4}{|c|}{$\begin{array}{l}\text { Dosage of } \\
\text { auxiliary material } \\
\text { [ppm] }\end{array}$} & \multirow[t]{2}{*}{$\begin{array}{l}\text { 28d } \\
\text { strength [Mpa] }\end{array}$} & \multicolumn{2}{|l|}{ working condition } \\
\hline & $\mathrm{YQ}$ & $\mathrm{HJ}$ & $\mathrm{HN}$ & $-\mathrm{C}$ & & initial & $60 \mathrm{~min}$ \\
\hline 1 & 3.5 & 25 & 42 & - & 52 & $\begin{array}{l}\text { good fluidity, } \\
\text { gravel shows and } \\
\text { bleeding }\end{array}$ & $\begin{array}{c}\text { flowing with little } \\
\text { speed, slump loss a lot }\end{array}$ \\
\hline 2 & 4.5 & 45 & 45 & - & 47 & $\begin{array}{l}\text { good fluidity, } \\
\text { good workability }\end{array}$ & $\begin{array}{l}\text { flowing with little } \\
\text { speed, a little slump } \\
\text { loss }\end{array}$ \\
\hline 3 & 5.5 & 48 & 48 & - & 44 & $\begin{array}{l}\text { good fluidity, } \\
\text { a little bleeding }\end{array}$ & $\begin{array}{l}\text { excellent station, } \\
\text { no slump loss }\end{array}$ \\
\hline 4 & 2 & 25 & 40 & 10 & 60 & $\begin{array}{l}\text { good fluidity, } \\
\text { good workability }\end{array}$ & $\begin{array}{l}\text { excellent station, } \\
\text { no slump loss }\end{array}$ \\
\hline
\end{tabular}

The results in Table 4 indicated that when introduce YQ, HJ, HN at 3.5ppm, 25ppm, 42ppm, the initial condition of concrete mixture could not get any improvement. While incresing the dosage of auxiliary materials, the strength reduced a lot. The ues of polycarboxylic type high performance water reducers cooperated with naphthalene series high range water reducing agents thereby markedly improved the workability of concrete mixture while without $28 \mathrm{~d}$ strength reduction.

\section{Conclusions}

When we control the temperature at $60 \sim 65^{\circ} \mathrm{C}$, addition time of copolymer monomers was for 3 hours, the reducing performance of water reducer is best.

Through High Performance Liquid Chroma-tography (HPLC) tests, we can find that our modified admixture's graph is almost the same with the famous brand abroad 3.

The ues of polycarboxylic type high performance water reducers cooperated with naphthalene series high range water reducing agents thereby markedly improv the workability of concrete and no strength reduction after 28 days.

\section{References}

[1] Chongzhi Li, Naiqian Feng etc. Journal of Building Materials.2004, 7(2).194-201(in Chinese)

[2] Qianping Ran, Dei Ding, Youkun You,etc. Journal of Functional Polymers,2004,17(1):159-164. (in Chinese)

[3] Kazuo Yamada,Tomoo Takahashi, Shunsuke Hanehara, et al. Cement and Concrete Research, 2000, 30(1):197-201

[4] Etsuo Sakai, Atsumu Ishida,Akira Ohta. Journal of Advanced Concrete Technology, 2006, 4 (2):211-223.

[5] Toyoth Nawa. Journal of Advanced Concrete Technology, 2006, 4(2):225 232. 